\title{
The Archive and the Closet: Same-Sex Desire and GDR Military Service in Stefan Wolter's Autobiographical Writing
}

Tom Smith, University College London/Worcester College, Oxford

This article analyses Stefan Wolter's memoir of his service as a Bausoldat in the Nationale Volksarmee: Hinterm Horizont allein - Der 'Prinz' von Prora (2005). I suggest the term 'archival narrative' to describe its narrative made up of juxtapositions of different sources and to draw attention to archival forces of selection, preservation and omission which the text displays. Wolter scrutinizes his documents of military service and highlights their inadequacy as evidence of his same-sex relationship, drawing attention to traces of his anxieties about revealing once closeted desires. The text therefore invites a reading through the archive theories of Jacques Derrida and José Esteban Muñoz, as well as Eve Kosofsky Sedgwick's concept of the closet. Wolter offers a uniquely candid account of same-sex desire in the East German military. He shows the effects of a closet defined by concealment, tacit knowledge and the threat of exposure on the documentation and archivization of queer experiences. Above all, he suggests ways of preserving evidence of same-sex desire without neglecting experiences of closeting and suppression.

Keywords: GDR, East Germany, Contemporary Literature, Autobiography, Archive, Desire, Queer, Memory, Military, Masculinity

Heiner Carow's film Coming Out premiered as the checkpoints along the Berlin Wall first opened on 9 November 1989, prompting the protagonist's 'coming out of the closet' to become a metaphor for the East German experience of the events of 1989 and reunification in 1990. ${ }^{1}$ The film's prominence amidst the upheavals of reunification meant that Carow brought queer experiences in the GDR to a widespread audience for the first time. ${ }^{2}$ Coming Out shows a conflict between the GDR's laws, according to which homosexuality had been legal since 1968, and the silence and intolerance which most frequently affected the public expression of same-sex desires and queer identities. ${ }^{3}$ Throughout the lifespan of the GDR, its repressive institutions remained particularly

\footnotetext{
${ }^{1}$ Coming Out, dir. by Heiner Carow (DEFA, 1989). See also Denis M. Sweet, 'Bodies for Germany, Bodies for Socialism: The German Democratic Republic Devises a Gay (Male) Body', in Gender and Germanness: Cultural Productions of Nation, ed. by Patricia Herminghouse and Magda Mueller (Oxford: Berghahn, 1997), pp. 248-62 (p. 250).

${ }^{2}$ The term 'homosexual' is most accurate for describing debates within the GDR, but I avoid it elsewhere because of its loaded and pseudo-medical associations at the time. My primary interest is same-sex desire, rather than the specific identities 'gay' or 'homosexual'. Where I do refer to experiences or identities based on same-sex desire, I instead use 'queer', a less restrictive term which I also take to imply a challenge to accepted categories of identity or ways of thinking. See Judith Butler, 'Critically Queer', in Bodies That Matter: On the Discursive Limits of 'Sex' (New York and London: Routledge, 1993), pp. 223-42.

${ }^{3}$ For example, Josie McLellan has described the struggles of gay and lesbian activists in the public sphere: 'Glad to Be Gay behind the Wall: Gay and Lesbian Activism in 1970s East Germany', History Workshop Journal, 74 (2012), 105-30.
} 
reticent about the presence of homosexuality, including the Volkspolizei denying the existence of homosexuality in its ranks altogether. ${ }^{4}$ In the case of the Nationale Volksarmee (NVA), its representatives vehemently opposed the relaxation of antihomosexuality legislation in the 1950s and 1960s, suggesting an anxiety about homosexuality in the military which belied the organisation's public silence on the matter. ${ }^{5}$ Indeed, the files of the Ministerium für Staatssicherheit (Stasi) reveal extensive investigations into homosexuality within the military. ${ }^{6}$ Even after decriminalization, homosexuals were considered unsuitable for military careers and were routinely dismissed. ${ }^{7}$ The sexual lives of unmarried enlisted men were carefully documented to reassure commanders that they were not homosexual. ${ }^{8}$ After reforms in 1988 brought the homosexual age of consent into line with the law on heterosexual sex, the military went so far as to issue secret guidelines on deftly circumnavigating the law in order to dismiss homosexuals from full-time military careers. ${ }^{9}$

Queer experiences in the GDR remain under-researched, despite the wealth of autobiographical and fictional representations which have emerged since the late 1980s and in particular since reunification. ${ }^{10}$ In this article, I present a memoir by the historian Stefan Wolter which sheds light on experiences of same-sex desire within the NVA and, above all, on the problems with documenting and articulating such desires during and

\footnotetext{
${ }^{4}$ See Mary Fulbrook, The People's State: East German Society from Hitler to Honecker (New Haven: Yale University Press, 2005), p. 165.

${ }^{5}$ Günter Grau, 'Return of the Past: The Policy of the SED and the Laws against Homosexuality in Eastern Germany between 1946 and 1968', Journal of Homosexuality, 37.4 (1999), 1-21 (pp. 16-17); Rüdiger Wenzke, Ulbrichts Soldaten. Die Nationale Volksarmee 1956-1971 (Berlin: Links, 2013), p. 377.

${ }^{6}$ A full discussion of same-sex desire in the NVA's institutional archives is beyond the scope of this article, but see e.g. BStU, MfS AOP 1761/80, files on an officer's desertion, 1978-79; BStU, MfS HA I/15134, reports on Operation 'Kapsel', 1977-82, fols 77-131.

${ }^{7}$ Wenzke, Ulbrichts Soldaten, p. 378.

${ }^{8}$ BStU, MfS HA I/16793, 'Analyse über ledige Offiziere im Verantwortungsbereich des GrenzkommandoSüd, die älter als 28 Jahre sind bzw. das 28. Lebensjahr erreicht haben', 19 April 1988, fols 1-7.

${ }^{9}$ BStU, MfS HA I/16634, memo from Generalmajor Teichmann with attachment 'Grundsätze für die Arbeit mit Bewerbern, Berufskadern und Angehörigen der NVA in Dienstverhältnissen auf Zeit bei Homosexualität', 21 October 1988, fols 88-91.

${ }^{10}$ Earliest publications include Ulrich Berkes, Eine schlimme Liebe. Tagebuch (Berlin and Weimar: Aufbau, 1987), and Jürgen Lemke, Ganz normal anders. Auskünfte schwuler Männer (Berlin and Weimar: Aufbau, 1989). Since reunification, see Jens Bisky, Geboren am 13. August. Der Sozialismus und ich (Berlin: Rowohlt, 2004), and Ingo Schulze, Neue Leben. Die Jugend Enrico Türmers in Briefen und Prosa. Herausgegeben, kommentiert und mit einem Vorwort versehen von Ingo Schulze (Berlin: Berlin Verlag, 2005).
} 
even after military service. ${ }^{11}$ Hinterm Horizont allein - Der 'Prinz' von Prora. Erfahrungen eines NVA-Bausoldaten (2005) describes Wolter's eighteen-month service between 1986 and 1988 in a so-called Baueinheit of the NVA. ${ }^{12}$ From 1964, conscientious objectors in the GDR were conscripted to work on construction projects, in Wolter's case at the harbour in Prora on Rügen. ${ }^{13}$ The Prora site was conceived as a National Socialist holiday camp in the 1930s, but was still unfinished when war broke out. During the war, the partially completed constructions housed a police battalion, communications workers and even forced labourers. ${ }^{14}$ The GDR inherited the buildings, which were converted into a military base in 1956 and by 1982 housed the largest contingent of so-called Bausoldaten. ${ }^{15}$ The men still wore military uniforms, lived in barracks and were trained by NVA officers, but were unarmed and worked on infrastructure projects in gruelling conditions. Post-reunification museums and historical accounts initially neglected Bausoldaten, as Wolter argues in his prologue: 'Über das Leben der Bausoldaten gibt es allgemein recht geringe Informationen.' (p. 18) Wolter therefore seems to have conceived his book as an urgent and highly personal contribution to the history of the GDR and of Prora. As a conscious contribution to historical debates, his memoir accordingly demonstrates a concern for factual accuracy and close attention to the reliability of sources.

Letters, photographs and facsimiles of other documents are central to the structure of Wolter's memoir, which brings these sources into dialogue with his memories as related through narrative reflections from a post-reunification perspective. In his prologue, he describes how he was inspired to write about his time in Prora by a visit to the site in 2004. The prologue then goes on to narrate events before Wolter's conscription,

\footnotetext{
${ }^{11}$ Except for Rüdiger Wenzke's short excursus on 'Männlichkeit und Homosexualität', homosexuality in the military remains entirely neglected by historical research: Ulbrichts Soldaten, pp. 375-78.

${ }^{12}$ Stefan Wolter, Hinterm Horizont allein - Der 'Prinz'von Prora. Erfahrungen eines NVA-Bausoldaten (Halle: Projekte, 2005): hereafter referenced in the text.

${ }^{13}$ See 'Anordnung des Nationalen Verteidigungsrates der Deutschen Demokratischen Republik über die Aufstellung von Baueinheiten im Bereich des Ministeriums für Nationale Verteidigung vom 7. September 1964', Gesetzblatt der Deutschen Demokratischen Republik, I, 1964, pp. 129-31.

${ }^{14}$ Bernd Eisenfeld and Peter Schicketanz, Bausoldaten in der DDR. Die 'Zusammenführung feindlichnegativer Kräfte’ in der NVA (Berlin: Links, 2011), pp. 177-78.

${ }^{15}$ For an introduction to Prora's history, see Martin Kaule, Prora. Geschichte und Gegenwart des 'KdFSeebads Rügen' (Berlin: Links, 2014).
} 
interspersing these reflections with photographs from his 2004 trip and with documents from 1986: a reproduction of his conscription order and transcriptions of diary entries and letters. The rest of the narrative is divided into chapters by month and depicts in strict chronology the monotony of daily life and his interactions with other Bausoldaten. Each chapter has two layers, beginning with Wolter's reflections and then collating transcriptions of the letters he wrote to his family. Photographs are also interspersed throughout the text, along with facsimiles of documents and pages of letters. The theme of same-sex desire only emerges from the dialogue between Wolter's memories and the documentary material he accumulated during and after his military service. His reflections describe his relationship with a fellow Bausoldat, named Thomas, and highlight the silence and anxiety surrounding this relationship in the documentary sources presented in the memoir.

I will first argue that the importance of sources in Hinterm Horizont allein can be best interpreted by understanding it as an archival narrative, that is, a narrative governed by the same dynamics of preservation, selection and exclusion as the process of archivization. The fact that gaps in the sources presented by Wolter are associated first and foremost with same-sex desire suggests that the closeted nature of his desires influenced his documentation and later narrativization of his construction service. I will therefore view the memoir through José Esteban Muñoz's discussions of the difficulties involved in preserving and accessing evidence of queerness, as well as through Eve Kosofsky Sedgwick's theory of the closet. This reading provides useful insights into Wolter's text while also revealing a close relationship more generally between the structures of the archive on the one hand and the closet on the other, with its implications of concealment, tacit knowledge and the threat of revelation that regulate expressions of same-sex desire. Hinterm Horizont allein demonstrates an ongoing tension in Wolter's engagement with same-sex desire and military service, even after reunification when such desires could be expressed with greater openness. Wolter's memoir performs the difficulties with accessing queer experiences through archival sources and even questions the ability of queer subjects to overcome such sources through memory and narrative, as the reader is exposed to the continuing impact of closet dynamics on Wolter's 
contemporary reflections on his construction service. The resulting text is a considered and empathetic engagement with his own same-sex desire during his service in the NVA and with issues of evidence and documentation.

I use the term 'archival narrative' for a text structured largely or entirely around interplay between different types and levels of sources and governed by the same processes as an archive. Archives of the GDR come in a range of forms, from the large official archives of the Stasi and other institutions which have received the greatest scholarly attention, to smaller private archives collected and organized by individuals, sometimes in secret or in opposition to more official archives. ${ }^{16}$ These diverse forms of archives are all shaped by certain power dynamics: as Michel Foucault has argued, processes of archivization assure that sources 'se groupent en figures distinctes, se composent les unes avec les autres selon des rapports multiples, se maintiennent ou s'estompent selon des régularités spécifiques'. ${ }^{17}$ That is to say, archivists select and preserve sources while also organizing them according to systems of categorization, which can establish the value of a given archival trace or diminish its integrity or individual importance, for example by merging files. As I will argue with reference to same-sex desire, these dynamics of ordering and collection are combined not just with the possibility that sources will 's'estomper' (blur), but with the potential for the archive or archivist to cause the suppression of material. In some ways, all narratives are governed by comparable processes of selection and organization of material, but archival narratives perhaps foreground more explicitly the processes by which sources are selected. In Wolter's case, for example, he undertakes a secondary process of re-selection and re-ordering, as he chooses a limited number of sources from his collection of letters, photographs and documents and arranges them in new ways to create the narrative text.

\footnotetext{
${ }^{16}$ Scholarship on archives from the GDR includes Alison Lewis, 'Reading and Writing the Stasi File: On the Uses and Abuses of the File as Autobiography', German Life and Letters, 56 (2003), 377-97; and contributions by Owen Evans and Regina Crise in Archive and Memory in German-Language Literature and Culture, ed. by Dora Osborne (=Edinburgh German Yearbook, 9 (2015)).

${ }^{17}$ Michel Foucault, L'archéologie du savoir (Paris: Gallimard, 1969), p. 170: 'group themselves together in distinct figurations, arrange themselves according to their multiple relations with one another, maintain their integrity or blur according to their specific regularities'.
} 
As Wolter's memoir suggests, archival narratives frequently stand in a complex relationship to archives and archival processes. For example, archivists not only preserve sources and reveal information but also relegate some material to less easily accessible sites and even wield the power to reject or destroy material which cannot be accommodated or goes against the archive's institutional focus. In many archives, this suppression of material is invisible to the user, whereas it may be possible for narratives to more clearly display these acts of suppression. In Hinterm Horizont allein, at least, Wolter repeatedly quotes from other letters, generally to his childhood friend Andreas, which demonstrate that the cache of letters in each monthly chapter is a deliberately incomplete reflection of his collection of sources (see pp. 269-70; 288). Like a narrator or autobiographer, many archivists also reserve the first rights to interpret archival material, and yet these interpretations do not generally become part of the archive itself. ${ }^{18}$ An archival narrative can therefore differ from an archive by combining sources with interpretations or evaluations: in Wolter's case, his interpretative reflections alternate with and interact with documentary sources. An archival narrative, furthermore, is also shaped by the qualities of narration: for example, Hinterm Horizont allein is ordered in a linear, paginated structure that determines the order in which sources are read. In Wolter's memoir, the interplay between archival processes and narrative interpretation brings out the importance of same-sex desire as a feature of his construction service, but also as the central factor which structures his memories and his later narration of his time in Prora.

The relation of memory to the documentary sources which Wolter presents is ambivalent, as his memories are frequently used to correct or expand on his letters and elucidate his photographs. Yosef Hayim Yerushalmi has insisted that 'the documents in an archive are not part of memory; if they were, we should have no need to retrieve them; once retrieved, they are often at odds with memory'. ${ }^{19}$ However, Wolter's archival narrative potentially indicates ways in which memories might be included alongside a more

\footnotetext{
18 Jacques Derrida highlights the interpretative monopoly of 'archontes' in ancient Greece: Mal d'archive: Une impression freudienne (Paris: Galilée, 1995), p. 13.

${ }^{19}$ Yosef Hayim Yerushalmi, 'Series Z: An Archival Fantasy', Journal of European Psychoanalysis, 3-4 (1997), unpaginated.
} 
conventional collection of written sources while retaining the tension between memories and sources that Yerushalmi describes. For example, the 'hypomnésique' quality of the archive - its function in externalizing and storing material memory by suppressing its spontaneous, interior qualities - has been discussed by Jacques Derrida in his essay Mal d'archive (1995). ${ }^{20}$ In Wolter's case, he gives textual form to his memories and uses them for a 'schonungslose Reflexion' on the sources, an interpretative step which underlines the fact that his is a narrative, rather than simply a published archive of sources (p. 32). Narrating his memories enables Wolter to evaluate the sources he has gathered and dispenses with any association between archive sources and authenticity. Rather, he explicitly identifies the bias in his sources. For example, moments of happiness and natural beauty assume a disproportionate place: 'Gern erwähnte ich in meinen Briefen Erlebnisse, die das Leben versüßten' (p. 122). Wolter's reflections thus comment on and supplement the somewhat sanitized portrayal of military service in his letters. Conventional archival sources become inseparable from their omissions and gaps, and the interplay between these sources and Wolter's reflections structures the entire work. The most prominent omissions in his letters concern his same-sex desire and intimacy. Wolter's reflections present his relationship with Thomas as a positive experience, which made his time in the NVA more bearable. Yet this experience is almost entirely suppressed by his letters, in which Thomas appears only as a friend.

The most prominent example of such an omission is their first kiss. Although a letter from the previous day announces, 'Morgen wollte ich mit Thomas in den Ausgang' (p. 293), Wolter's next letter neglects the evening entirely. Unlike Wolter's other evenings in the local town, his leave on this occasion is omitted from his correspondence with his parents. This evening is described in vivid terms in his reflections. Wolter remembers dancing with Thomas because no girls would dance with the two young men in uniform. Wolter's portrayal is extremely intimate: 'Es fanden sich die Augen, die zuletzt so viel Gleiches gesehen hatten, und es fanden sich die Hände, die in Gleichem Geborgenheit finden wollten.' (p. 285) Repetition of 'gleich' relates their same-sex intimacy and desire to their shared experience of Prora. They are ejected from the bar for their physical

\footnotetext{
${ }^{20}$ Derrida, Mal d'archive, p. 26.
} 
intimacy: 'Schwule können wir hier nicht brauchen.' (p. 286) When they then stumble and fall walking through the woods on the way back to barracks, they land on top of one another. Wolter writes, 'Während es mir heiß durchflutete, so nahe bei einem Menschen zu sein, mit dem sich mein Inneres längst verbunden hatte, fühlte ich einen zarten Biss am Hals [...] Da trafen sich die Lippen. Im Vertrauen auf meinen älteren Freund gab ich mich der Zartheit hin' (ibid.). Wolter's flush seems to be a physical manifestation of his desire. He is initially reluctant when Thomas kisses him, before he gives way and experiences a physical and emotional release. The language of these passages is incongruous, using a less matter-of-fact tone than earlier reflections and describing their physical intimacy with great pathos. Wolter thus reinstates experiences of desire that were suppressed from his letters, while his flush and intense, incongruous prose gesture to physical and emotional qualities that remain unarticulated.

Wolter's archival narrative thus uses his memories to reveal the selective image of his construction service which is presented in his documentary sources, which tend to conceal and suppress evidence of his relationship with Thomas. Initially, this association between archive sources and suppression recalls Derrida's prominent discussion of the importance of suppression to the functioning of archives in Mal d'archive. Derrida describes archival structures in psychoanalytic terms as an interplay between disorderly and contradictory drives: an archive drive to recover and preserve is balanced by a destruction drive, associated with the loss that occurs when something is articulated. These drives produce a mania that he calls a 'mal d'archive'. Material that is not preserved, he argues, is not simply repressed, which would amount to archivization in the unconscious, but suppressed, a more conscious and destructive silencing. ${ }^{21}$ Derrida's essay does not differentiate particularly between different forms of archive, and although his model offers a productive way into a personal archival narrative like Wolter's, this requires some qualification. As Hinterm Horizont allein is the narrative of an individual, the archival dynamics within the text can plausibly be understood in terms of drives and compulsions. Yet the suppression of experiences of desire and intimacy in sources across all levels of the text cannot be solely accounted for in terms of the archive's structural

\footnotetext{
${ }^{21}$ Derrida, Mal d'archive, p. 38.
} 
dynamics, even where these can be related to the psychology of an individual. The wider context must be considered, as the expression of same-sex desire in the NVA and after reunification is circumscribed in specific ways which influence its manifestations in the layers of Wolter's narrative.

There are a number of potential reasons for Wolter suppressing same-sex intimacy in his letters during military service. Conscripts could never be sure whether their post was being read by officers, which in fact seems to have been unusual, or the Stasi, which was very common. ${ }^{22}$ Wolter may well have worried about repercussions if his commanding officers discovered his relationship with Thomas by reading his letters. Yet elsewhere the letters describe his working conditions at length, despite the prohibition on describing military installations, so the omissions of his same-sex desire from letters cannot be simply explained by fear of punishment. More probably, same-sex desire is suppressed because of wider prohibitions on homosexuality in GDR society, which are exacerbated by the fact that Wolter and his family were religious and did not accept homosexuality, at least at first: 'In Eisenach, in meinen kirchlichen Kreisen, war dafür kein Platz.' (p. 42) In this context, Wolter's omissions in his letters might have been expected, even if they were not penned while in the NVA. Yet the highly normative context of the NVA seems to exacerbate his fear of leaving traces of same-sex desire. Wolter's reflections repeatedly place his relationship with Thomas in the context of the military's rejection of homosexuality. Even though he and Thomas find space to express their desire, this is always in hidden, unobserved places: 'Sooft wir allein waren, nahm einer den anderen in eine dunkle Ecke, wo wir uns, von den anderen unbemerkt, umarmten' (p. 288). Wolter thus foregrounds the difficulties in expressing same-sex desire in the Baueinheit itself, and relates them to his later struggle to integrate his relationship with Thomas into his autobiographical account of his construction service.

The suppression of same-sex desire in Hinterm Horizont allein must therefore be interpreted in the context of wider prohibitions in the GDR, which act alongside and

\footnotetext{
${ }^{22}$ See the Stasi's discussions and evaluations of a comprehensive post monitoring campaign in a border regiment: BStU, MfS HA I/16870, 'Abschlußeinschätzung des Führungsbeispiels in der Unterabteilung Abwehr GR-23 Kalbe/M. - GK Nord’, 25 November 1987, fols 38-43.
} 
through the archival dynamics of suppression described by Derrida. In Wolter's narrative, prohibitions on the expression of same-sex desire appear to be internalized and the desire closeted. In Epistemology of the Closet, Eve Kosofsky Sedgwick emphasizes the interplay between this internalized need to suppress queer desires and the spaces and freedoms that the closet can create. $^{23}$ The queer subject engages in recurring, performative acts of concealment or of coming out, and others also participate in this play of knowledge and ignorance by exposing or refusing to acknowledge queer desires. ${ }^{24}$ The workings of knowledge and power in Sedgwick's concept coalesce around the figure of the 'glass closet':

The glass closet can license insult ('I'd never have said those things if I'd known you were gay!' - yeah, sure); it can also license far warmer relations, but (and) relations whose potential for exploitiveness is built into the optics of the asymmetrical, the specularized, and the inexplicit. ${ }^{25}$

Sedgwick's metaphor emphasizes the power imbalances implied by the open secret of same-sex desire, as the walls of the glass closet can be more or less transparent. By describing relations centred on 'the inexplicit', she relates power imbalances to uncertainties around evidence of queer desires: these uncertainties can generate space for same-sex intimacies by protecting them from prohibitions, but they also present difficulties for the documentation and articulation of same-sex desires in narratives such as Wolter's.

The closet governing same-sex desire in the NVA and wider GDR society is thus an important structuring factor of Wolter's archival narrative. Although concealing their desires may have allowed the two men to share private intimacies within the military institution, Wolter's later narrative repeatedly draws attention to the omission of their relationship from letters and photographs documenting his military service. This tension suggests that same-sex desire occupies a uniquely fraught place within Wolter's sources, an aspect which has been explored by the queer theorist José Esteban Muñoz, whose

\footnotetext{
${ }^{23}$ Eve Kosofsky Sedgwick, Epistemology of the Closet (Berkeley: University of California Press, 1990).

${ }^{24}$ Ibid., p. 68.

${ }^{25}$ Ibid., p. 80.
} 
work helps illuminate the particular combination of closet and archival dynamics in Wolter's narrative. According to Muñoz,

leaving too much of a trace has often meant that the queer subject has left herself open for attack. Instead of being clearly available as visible evidence, queerness has instead existed as innuendo, gossip, fleeting moments, and performances that are meant to be interacted with by those within its epistemological sphere. ${ }^{26}$

For Muñoz, the expression and archivization of queerness are shaped by danger: rather than simply suppressing or effacing queer desire, as Derrida's model might suggest, archivization enables evidence to be mobilized against the queer subject. This danger shows how archives and their structures of revelation and concealment are complicit in, and yet also shaped by, the exploitation of knowledge and ignorance that are so central to Sedgwick's concept of the closet.

Wolter's suppression of same-sex desire in his letters is one response to the danger that any textual trace of his relationship with Thomas might be used to punish him and to define his sexual identity against his wishes. However, his narrative in fact suggests ways of acknowledging this suppression while creating space for queer experiences. For example, Muñoz also suggests ways in which archives or, by extension, archival narratives, might make space for queer experience. He sets out a concept of 'queer evidence: an evidence that has been queered in relation to the laws of what counts as proof' ${ }^{27}$ Hinterm Horizont allein has already shown the association between conventional written sources and the suppression of same-sex desire, subverting the status of these archival sources as evidence of queer desires in any traditional sense. Muñoz suggests instead that queer evidence might entail a combination of conventional archival documents and ephemeral forms of evidence. In Cruising Utopia (2009), he analyses gesture and dance, but his earlier emphasis on 'innuendo, gossip, fleeting moments, and performances that are meant to be interacted with' points to alternative

\footnotetext{
${ }^{26}$ José Esteban Muñoz, 'Ephemera as Evidence: Introductory Notes to Queer Acts', Women and Performance, 8.2 (1996), 5-16 (p. 6).

${ }^{27}$ José Esteban Muñoz, Cruising Utopia: The Then and There of Queer Futurity (New York: New York University Pres, 2009), p. 65.
} 
forms of ephemera. ${ }^{28}$ The memories which are so central to Wolter's narrative, for example, might also be considered ephemeral evidence. Interaction is also central to Muñoz's concept of the archive, and the interaction between layers of sources which reveals the suppression of same-sex desire in Wolter's memoir could potentially draw critical attention to the influence of closet structures on evidence and archivization. The remainder of this article analyses the wider impact of the closet on this text and explores the queer approaches to evidence and to past military experiences which Wolter's narrative suggests.

One decidedly queer use of his memories and archival sources in Wolter's memoir is his reclaiming of his nickname. Comrades called him 'Prinz' to mock his supposedly affected behaviour and the apparent preferential treatment he received, because of a medical assessment which exempted him from drill and ensured he was allocated less manual labour. His comrades even feminized the nickname as 'Prinzessin auf der Erbse' or 'Prinzessin Stefanie', a reference to a recent song released by Princess Stéphanie of Monaco (pp. 114, 157, 207-8). Wolter later published a reader's letter which suggests that such feminine nicknames were commonly used in mocking, but also at times affectionate ways. ${ }^{29}$ Although the quotation marks in the subtitle, Der 'Prinz' von Prora, are perhaps reminiscent of Wolter's comrades' mocking, they also signal an ironic performance in the narrative of the nickname's positive connotations, perhaps suggesting mastery over experience through a confident self-fashioning as the 'Prince of Prora'. Wolter's reflections also recast the name in a positive light, notably when, curled up with Thomas, he feels like 'ein kleiner Prinz' (p. 199). This allusion to Antoine de SaintExupéry's Le Petit Prince might further emphasize the strange and alienating nature of the military environment in which Wolter and Thomas find themselves.

Wolter also uses his sources to depict and reclaim certain affectations which elicited his comrades' mocking in the first place, by including photographs in which his poses exude confidence and care for his appearance. In the image on the memoir's cover, Wolter

\footnotetext{
${ }^{28}$ Ibid.; Muñoz, 'Ephemera', 6.

${ }^{29}$ Stefan Wolter, Der 'Prinz von Prora' im Spiegel der Kritik. Das Trauma NVA und WIR (Halle: Projekte, 2007), p. 81.
} 
displays a confident individuality, with a sideways glance toward the camera and his signature raised collar. This creative touch to the NVA uniform was an attempt to personalize it, which comrades appear to have mocked as an affectation. A similar image of Wolter with three other soldiers on the beach further emphasizes his self-awareness: he is the only one who appears to be posing for the camera (p. 169). In a later publication describing the reception of his memoir, Wolter includes a particularly queer image, in which he models his uniform with hand on hip and a strong, confident, even defiant gaze directly into the camera. ${ }^{30}$ Photographs of him posing playfully like this display his maintenance of individuality and self-expression, turning previously ridiculed behaviour into performative and potentially subversive resistance to the NVA's attempts at controlling its conscripts' self-expression.

In line with his defiant reclaiming of the 'Prinz' nickname, Wolter's memoir appears at first glance to present a single, coherent development narrative that leads from his initial naivety to his acceptance of his desires. This development appears to be initiated by military service and continues in the openness of the post-reunification environment. Wolter's prologue mentions Thomas four times without explaining their relationship, a technique which suggests that the whole narrative emanates from these spontaneous recollections. Wolter's relationship with his best friend, Andreas, which in his sister's view gave him 'den Eindruck eines Schwulen' (p. 42), is then used to suggest a predisposition to intimate male-male friendship, as Wolter himself later comments. ${ }^{31} \mathrm{On}$ entering the NVA, he believes that same-sex desire has 'keine Existenzberechtigung' ( $p$. 120), but exposure to gay and bisexual Bausoldaten challenges his views. His kiss with Thomas is a turning point, demonstrating Wolter's acceptance of his same-sex desire. Wolter's development could be viewed as a coming-out narrative, culminating in the publication of Hinterm Horizont allein. However, this interpretation might oversimplify Wolter's engagement with same-sex desire in the memoir. Hinterm Horizont allein is not a simple revision of the archive to accommodate same-sex desire; rather, his reflections still perform and are shaped by closet dynamics.

\footnotetext{
${ }^{30}$ Ibid., p. 202.

${ }^{31}$ Ibid., p. 26.
} 
For instance, Wolter's depiction of other conscripts demonstrates how closet dynamics vary across narrative layers. His ambivalent depiction of an openly gay comrade, Jan, is one example. Wolter's letters describe Jan in exasperated, homophobic tones that reinforce prohibitions on same-sex desire: 'Unser Schwuli schläft gerade in einer Ecke, Michael und ich gehen ihm so weit es möglich ist aus dem Weg' (p. 129). Wolter's reflections complicate this picture, explaining how he was pursued by Jan but also how he played with Jan's desire: 'Er spielte mit mir und ich mit ihm' (p. 120). Wolter even envies Jan for one consequence of the NVA's prohibitions on same-sex desire: 'Da Jan geoutet schwul war, gehörte er [...] zu den Glücklichen, die Duschbefreiung erhalten hatten [...] Das schien beneidenswert' (ibid.). Jan's case demonstrates that closet dynamics in Wolter's unit both suppressed and provided space for queer desires, in line with Sedgwick's definition. Jan's openness provokes both censure and playful homoeroticism from Wolter and, surprisingly even in the late 1980s, the NVA does not dismiss Jan but tacitly tolerates his desires in all contexts but the communal showers. By supplementing his earlier insults with more empathetic reflections, Wolter perhaps atones for imposing a closet on Jan in his letters. Yet by presenting Jan, a conscript who explicitly identifies as gay, Wolter also creates a contrast with his refusal to define or categorize his own desire. This contrast potentially re-imposes closet dynamics of concealment and uncertainty, in that Wolter gives the reader knowledge of Jan's sexual identity while remaining inexplicit regarding his own.

The continuing impact of the closet is tied to Wolter's anxiety regarding same-sex desire, which might be conceptualized with Derrida as a 'mal d'archive' in relation to the suppression of his desires in his letters. In a later volume documenting the memoir's reception, entitled Der 'Prinz von Prora' im Spiegel der Kritik (2007), Wolter writes that losing influence over interpretations of his text after publication gave him panic attacks: 'Das Buch [...] hatte zwar dazu beigetragen, den Frieden mit Prora zu finden. Mit dem Buch selbst aber musste ich ihn erst mühsam schließen.' ${ }^{32}$ The loss of control over his text appears to have prompted a drive to write about his story further in order to control its reception. Same-sex desire is the primary object of Wolter's anxiety: 'Meine größte

\footnotetext{
${ }^{32}$ Wolter, Der 'Prinz von Prora' im Spiegel der Kritik, p. 12.
} 
Sorge war, die Geschichte mit Thomas könne von der politischen Aussagekraft des Buches ablenken und es zu persönlich werden lassen'. ${ }^{33}$ Wolter even describes giving an interview after the publication of Hinterm Horizont allein in which he denied any relationship beyond 'geistig-seelische Nähe'. ${ }^{34}$ In remembering this interview, Wolter ultimately reasserts the importance of his physical intimacy with Thomas: 'Tatsächlich hat doch gerade auch die körperliche Nähe über vieles hinweggeholfen'. ${ }^{35}$ His later engagement with his memoir thus reveals his multiple, recurring acts of coming out, repeatedly explaining, justifying and contextualizing the place of his same-sex desire within his military service and his post-reunification identity. His desire for and intimacy with Thomas is by turns affirmed and downplayed in a variety of ways, and Wolter continues to explore ways of representing this desire while preserving the protection that can be afforded by the silences and uncertainties of the closet.

Hinterm Horizont allein reveals that, at least in some cases, the existence of desire and intimacy between soldiers was known about by conscripts and commanding officers, while nonetheless showing that knowledge of same-sex desire could be accompanied by prohibitions and censure, as in the case of Jan. In Wolter's case, a same-sex relationship was even integral to making military service more bearable, but this was dependent on discretion, stolen moments and a conscious silence in letters and other documents. Wolter's archival narrative chooses to emphasise particularly the absence of his relationship with Thomas from his letters and photographs through the choice of archival sources included in the narrative. Yet Wolter's memories and reflections, as well as his apparent willingness to reveal details of his relationship with Thomas, give us no reason to expect that the sources presented in Hinterm Horizont allein are anything other than representative of the silence surrounding his desires in the documents and sources he has gathered. Indeed, his later work Der 'Prinz von Prora' im Spiegel der Kritik suggests that his anxiety about expressing his desire in the military context and to his parents is continued in his anxiety about the interpretation of his published revelations. This single portrayal cannot be representative, particularly since Baueinheiten were filled with men

\footnotetext{
${ }^{33}$ Ibid., p. 11.

${ }^{34}$ Ibid., p. 74.

${ }^{35}$ Ibid., p. 75.
} 
who were already outsiders in GDR society and it is possible that they therefore had more queer conscripts in their ranks than regular units. Nevertheless, Wolter's narrative is extremely useful for showing not just the homophobic environment of the NVA, but the range of ways in which individual conscripts explored and concealed their same-sex desire. By constructing his narrative out of layers of documents and later reflections, Wolter performs on a narrative level the dynamics of concealment and revelation over time which are so central to Sedgwick's concept of the closet. The text therefore highlights the closet dynamics that governed same-sex desire within the NVA.

Wolter's text, moreover, draws attention to the interplay between the archive and closet as structural forces. The dynamic of suppression and revelation, which is shared by the archive and the closet, is central to Wolter's archival narrative. Different versions of his desire emerge from the layers of the narrative, with his letters, photographs and reflections suppressing and revealing same-sex desire in different ways. It is perhaps unsurprising that prohibitions on expressing queer experience should have affected Wolter's documentation of his relationship with Thomas, not to mention the impact of the material conditions of military service, in which writing had to be furtive and photography was not permitted within the base. However, the extent to which the gaps in his archive map onto the closeting of same-sex desire is significant. The text reveals a complex dialectical relationship between archive and closet. In a society such as the GDR where same-sex desire was governed by the closet, the production of evidence of this desire was affected. This influence of closet dynamics could take several forms: official documents from the GDR are often silent about same-sex desire, or else are concerned with proving citizens' homosexuality and punishing any transgressions where possible. In Wolter's case, however, the closet imposed by GDR politics and society results in more personal difficulties articulating queer desires. Even after reunification, his memories of military service never quite escape the closet. Indeed, the 'mal d'archive' that structures Hinterm Horizont allein seems driven almost entirely by Wolter's negotiations of closet dynamics in contemporary society, even as he attempts to overcome the impact of the closet on archival traces of his military service. Even highly personal archival narratives such as this can therefore function not to preserve or exhibit desire, but to perpetuate its 
concealment and suppression even as they create spaces for articulating these desires: in short, the archive begins to function as a closet.

The relationship between archival and closet dynamics in Wolter's text suggests possibilities for a queer archive that more adequately represents same-sex desire. By foregrounding not just his relationship with Thomas but his difficulties writing about it, Wolter's memoir highlights how same-sex desire is suppressed within his narrative as well as how it is represented. The text uses similar methods to those described by Muñoz, combining ephemeral sources - Wolter's memories - with more conventional documentary traces of his military service. It is above all the dialogue between these layers of evidence that hints at Wolter's desire, drawing on the interactions which are central to Muñoz's concept of queer evidence. By adding his memories to more conventional sources, Wolter suggests how a queer archive might take shape along similar lines to his archival narrative: out of layers of ephemeral and documentary sources, with memories captured in order to contrast them with documents, letters, photographs and other sources. The authenticity or superiority of documentary evidence is refuted by Wolter's text, which compares them to memories which exceed the letters and reveal aspects which have been suppressed. Yet he also resists the temptation to present his memories as sovereign, by showing them being prompted by and even dependent on documents and sources, just as they are conditioned by continuing negotiations of closet structures and ongoing anxieties regarding same-sex desire. The boundaries are thus blurred between forms of evidence. Most importantly, Wolter's approach does not seek to overcome the effects of closeting on his desires. Instead, he critically demonstrates the different ways in which closet dynamics motivate the suppression of same-sex desire, denying that any of his epistolary or narrative negotiations of queer military experiences is more coherent or correct than any other.

The value of Wolter's text thus extends beyond its autobiographical or historical functions as an insight into the experiences of Bausoldaten or into the place of same-sex desire in the context of military service in the GDR. In drawing on and performing the archival dynamics which I outlined at the beginning of this article, and which have been 
the subject of much debate across the humanities and social sciences, Wolter illustrates the other ideological and cultural factors which affect the process of archivization and the preservation of evidence. As regards same-sex desire, the potential for 'attack' associated with conventional archives by Muñoz is shown in Wolter's narrative to affect not just what sources are preserved, but the production of sources in the first place. This chimes with Foucault's argument that 'l'archive, c'est d'abord la loi de ce qui peut être dit, le système qui régit l'apparition des énoncés comme événements singuliers'. ${ }^{36}$ Yet contrary to Foucault's argument and to Derrida's psychoanalytic interpretation in Mal d'archive, the law governing what can be said is not determined by the implications of the archive's categories and power structures alone. Wolter's text makes explicit the closet structures which cause the suppression of same-sex desire in ways which precede archivization, and yet nonetheless continue to influence the archival narrative and, by implication, archive structures themselves.

Wolter's narrative further suggests that memories can reveal and even subvert the suppression of queer experiences in archives when they are brought into dialogue with more conventional forms of documentary and photographic evidence. Such an approach is being explored outside the confines of archival narration by contemporary queer archives in Germany, which have begun to establish archives of queer memories. For example, the Bundesstiftung Magnus Hirschfeld has recently inaugurated a so-called Archiv der anderen Erinnerungen, which explores the possibilities of archiving memories of queer life in both post-war German states in the form of video interviews. Like Wolter's narrative reflections, these videos necessarily reduce the ephemeral qualities of memories to concrete textual forms which can be preserved as sources. Yet in the process, queer voices enter into the archive as alternative evidence of same-sex desire which can supplement official documents on queer experience. Wolter's approach suggests ways of reading these different sources in dialogue with one another, in a way which not only reveals queer desires, but foregrounds the layers of suppression and

\footnotetext{
${ }^{36}$ Foucault, L'Archéologie du savoir, p. 170: 'The archive is, first and foremost, the law determining what can be said, the system governing the appearance of statements as singular events'.
} 
mediation to which they have been subjected as they are articulated, documented and preserved.

Tom Smith was recently awarded his $\mathrm{PhD}$ from University College London and teaches modern German literature and film at Worcester College, Oxford. His research interests include postwar and contemporary literature and film, gender and queer studies, critical theory and the role of music in German-language culture. He has published on the works of Helga Königsdorf and on uniform and the body in representations of the East German military. 